\title{
Yağ Gülü (Rosa damascena Mill.)'nün Mikroçoğaltımında En Uygun Sürgün ve Köklenme Ortamlarının Belirlenmesi
}

\author{
Ramazan DÍLMEN1 1 , Nilgün GÖKTÜRK BAYDAR ${ }^{* 2}$ (1) \\ 1,2Isparta Uygulamalı Bilimler Üniversitesi, Ziraat Fakültesi, Tarımal Biyoteknoloji Bölümü, 32260, Isparta, \\ Türkiye
}

(Alınış / Received: 30.01.2020, Kabul / Accepted: 17.03.2020, Online Yayınlanma / Published Online: 20.04.2020)

\author{
Anahtar Kelimeler \\ Rosa damascena, \\ Yağ gülü, \\ Mikroçoğaltım, \\ In vitro
}

Özet: Bu araştırma, ekonomik değerinin yanı sıra ülkemiz açısından bir prestij bitkisi olması nedeniyle de büyük önem taşıyan yağ gülü (Rosa damascena) için in vitro koşullarda etkili ve uygun maliyetli sürgün çoğaltma ve köklenme protokolü geliștirmek amacıyla gerçekleștirilmiștir. Bu araştırmada eksplant kaynağı olarak yağ gülü bitkilerine ait tek gözlü boğum parçaları kullanılmıștır. Sıvı modifiye MS ortamına ilave edilen benziladenin (BA) (1.0, 1.5 ve $2.0 \mathrm{mg} / \mathrm{l})$ 'nin 0 ve $0.1 \mathrm{mg} / \mathrm{l}$ konsantrasyonlarındaki naftalin asetik asit (NAA) ile yapmış olduğu 6 farklı kombinasyonunun, boğum eksplantlarından elde edilen in vitro sürgünlerin gelişimi üzerine olan etkileri belirlenmiştir. Yapılan üç alt kültür sonrasında elde edilen sürgünler, $2 \mathrm{mg} / \mathrm{l}$ indol bütirik asit (IBA), $30 \mathrm{~g} / \mathrm{l}$ sakkaroz ve $162 \mathrm{mg} / \mathrm{l}$ floroglusinol (FG) içeren $1 / 2 \mathrm{MS}$ ortamında 7 gün karanlıkta kültüre alınmalarının ardından, köklenme performanslarını değerlendirmek üzere, sıvı $1 / 2$ MS ve sıvı $1 \frac{1}{2}$ modifiye MS ortamlarında kültüre alınmışlardır. Araştırma sonucunda, sürgün çoğalması ve büyümesi için $2 \mathrm{mg} / \mathrm{l} \mathrm{BA}$ içeren sıvı modifiye MS ortamının; sürgünlerin köklendirilmesi için de 7 gün süreyle $2 \mathrm{mg} / \mathrm{l}$ indol bütirik asit (IBA), $30 \mathrm{~g} / \mathrm{l}$ sakkaroz ve $162 \mathrm{mg} / \mathrm{l} \mathrm{FG}$ içeren MS ortamında tutulmalarının ardından, sadece $30 \mathrm{~g} / \mathrm{l}$ sakkaroz içeren sıvı $1 / 2 \mathrm{MS}$ ortamlarına transfer edilmeleri ile en başarılı sonuçların elde edildiği belirlenmiş̦tir. Araştırmada ayrıca düşük maliyet ve yüksek başarı ile Rosa damascena türü için sıvı ortamların etkin bir şekilde kullanılabileceği de belirlenmiştir.

\section{Determination of the Most Appropriate Shoot and Rooting Media in the Micro- propagation of Oil Rose (Rosa damascena)}

\section{Keywords}

Rosa damascena,

Oil rose,

Micropropagation, In vitro

\begin{abstract}
This study was carried to improve an influential and cost-effective shoot proliferation and rooting protocol for oil rose (Rosa damascena) having great importance of its economic value as well as its prestige plant for our country. In this study, single nodal pieces belonging to oil rose plants were used as explant sources. It was determined that the effects of liquid modified Murashige and Skoog (MS) media containing 6 different combinations of benzyladenine (BA) $(1.0,1.5$ and $2.0 \mathrm{mg} / \mathrm{l})$ and naphthalene acetic acid (NAA) $(0$ and $0.1 \mathrm{mg} / \mathrm{l})$ on the development of shoots obtained from nodal explants. After three subculture cycles, to evaluate rooting performance of shoots, they were cultured in $1 / 2$ MS medium containing $2 \mathrm{mg} / \mathrm{l}$ indole butyric acid (IBA), $30 \mathrm{~g} / \mathrm{l}$ sucrose and $162 \mathrm{mg} / \mathrm{l}$ phloroglucinol (PG) for 7 days in the dark and then transferred to liquid $1 / 2 \mathrm{MS}$ and liquid $1 / 2$ modified MS medium. At the end of the study, the most successful results for shoot proliferation were obtained from the liquid modified MS medium containing $2 \mathrm{mg} / \mathrm{l} \mathrm{BA}$. The best treatment for rooting of shoots was MS medium supplemented with $2 \mathrm{mg} / \mathrm{l}$ indole butyric acid (IBA), $30 \mathrm{~g} / \mathrm{l}$ sucrose and $162 \mathrm{mg} / \mathrm{l}$ PG for 7 days and then transferring the explants to liquid $1 / 2$ MS medium added only $30 \mathrm{~g} / \mathrm{l}$ sucrose. In the study, it was also determined that liquid media had significant potential for the propagation of Rosa damascena with low cost and high success.
\end{abstract}




\section{Giriş}

Yağ gülü (Rosa damascena Mill.), Rosaceae familyasının Rosa cinsi içinde yer alan çok yıllık bir bitki türüdür. Dünyada 150, Türkiye'de ise 25 gül türü bulunmakla beraber, bu türler içinde çok azı kuvvetli kokuya sahip bulunmaktadırlar. Rosa damascena, Rosa centifolia, Rosa alba ve Rosa moschata kokulu gül türleri içinde en önemli olanlarıdır [1]. Rosa gallica L. ve Rosa phoenicia Boiss. türlerinin doğal melezi olan ve "Isparta gülü" ya da "Pembe Yağ Gülü" olarak da isimlendirilen $R$. damascena, kendine özgü keskin ve yoğun kokusu ile başta parfüm ve kozmetik olmak üzere ilaç ve gıda endüstrisi gibi birçok alanda kullanılma potansiyeli bulunan bir gül türüdür [2].

Dünyada Bulgaristan, İran, Hindistan ve Çin'de önemli miktarda yetiştirilen $R$. damascena, ülkemizde, Göller Bölgesi olarak da adlandırılan, içinde Isparta, Burdur, Afyon, Denizli ile Konya ve Antalya'nın bir bölümünün yer aldığı yörede üretilmektedir. Yağ gülünden elde edilen başta gül yağı olmak üzere, gül suyu, gül konkreti ve gül absolütü içermiş oldukları uçucu bileșenlerle kozmetik ve parfümeri sanayinde yoğun talep görmektedirler. Bütün bunların yanı sıra tıpta birçok hastalığa karşı koruma, önleme, tedavi etme gibi özellikleri de bulunan bu ürünler, gıda sanayinde, kişisel bakım ve temizlik ürünlerinde de kullanılmaktadırlar [3,4,5].

Yağ gülü genel olarak ya tohum ya da çelik, kök sürgünleri, daldırma ve aşı gibi vejetatif çoğaltma yöntemleriyle çoğaltılmaktadır [6]. Anaç üretimi ve ıslah amaçlı çalışmalarda kullanılan tohumla çoğaltma, generatif yöntem olup, bu şekilde elde edilen bitkiler arasında geniş bir açlım bulunur. Zaman alıcı uygulamaları içeren vejetatif çoğaltma yöntemlerinin ise mevsimlere ve yıllara göre elde edilen başarının farklı olması, fidan elde etme oranının düşük olması, arazi, iş gücü ve yoğun tarımsal uygulamalara ihtiyaç göstermesi gibi birçok dezavantajları bulunmaktadır $[7,8]$. Son yıllarda yağ gülünün çoğaltılması sırasında yaşanan bu olumsuzlukları ortadan kaldırmak için doku kültürü teknikleri alternatif bir çoğaltma yöntemi olarak önem kazanmaya başlamıştır. Doku kültürü ile çoğaltma bir diğer ifade ile mikroçoğaltım, yılın her döneminde kısa sürede ve çok sayıda bitki elde etme olanağı sunan, tamamen kontrollü koşullarda ve yapay besin ortamlarında eksplant adı verilen küçük bitki parçalarının kullanılmasıyla gerçekleştirilen bir çoğaltma tekniğidir [3]. Sahip olduğu avantajlar nedeniyle yağ gülünün çoğaltımında özellikle son yıllarda mikroçoğaltımın büyük önem kazandığı görülmektedir.

$\mathrm{Bu}$ araştırma, ülkemiz açısından ekonomik değerinin yan sıra bir prestij bitkisi olması nedeniyle de büyük önem taşıyan yağ gülü için in vitro koşullarda etkili ve uygun maliyetli sürgün çoğaltma ve köklenme protokolü geliştirmek amacıyla gerçekleştirilmiştir.

\section{Materyal ve Metot}

\subsection{Materyal}

Araştırmada eksplant kaynağı olarak Isparta Uygulamalı Bilimler Üniversitesi Ziraat Fakültesi Araştırma ve Uygulama Bahçesi'nden temin edilen yağ gülü $(R$. damascena $)$ bitkilerine ait yeşil sürgünlerin orta kısımlarından alınan 0.4-0.6 cm kalınlığa sahip yaklașık 1-1.5 cm uzunluğundaki tek gözlü boğum parçaları kullanılmıştır.

\subsection{Metot}

\subsubsection{Bitkisel materyallerin sterilizasyonu ve besin ortamlarında kültüre alınmaları}

Eylül döneminde alınan yeşil sürgünler, üzerindeki yapraklar uzaklaştırıldıktan sonra 20 dakika boyunca akan çeşme suyu altında yıkanmıştır. Yıkama işlemi sona erdikten sonra, her birinin üzerinde bir boğum olacak şekilde parçalara ayrılan sürgün parçaları, $\% 70$ 'lik etil alkolde 30 saniye bekletilip, ardından $\% 0.1$ civa klorür $\left(\mathrm{HgCl}_{2}\right)$ ile 5 dakika süreyle yüzey sterilizasyonuna tabi tutulmuştur. Ardından her biri 5'er dakika olmak üzere $3 \mathrm{kez}$ steril saf su ile yıkanan eksplantlar, daha sonra içinde $30 \mathrm{~g} / \mathrm{l}$ sakkaroz, $7 \mathrm{~g} / \mathrm{l}$ agar bulunan katı Murashige ve Skloog (MS) [9] besin ortamında kültüre alınmıştır. İçinde $50 \mathrm{ml}$ besin ortamı bulunan 250 ml'lik erlenlere dikilen eksplantlar, daha sonra sicaklığ $24 \pm 1^{\circ} \mathrm{C}$ olarak ayarlanmış büyütme kabininde 16 saat aydınlık, 8 saat karanlık ve 3000 lüks ışık yoğunluğu koşullarında kültüre alınmıștır.

\subsubsection{Sürgünlerin çoğaltılması}

Kültüre alındıkları besin ortamında sürerek yaklaşık 4-5 cm uzunluğuna gelen sürgünler, daha sonra sürgün ortamlarına alınarak çoğaltılmaları sağlanmıştır. $\mathrm{Bu}$ amaçla temel besin ortamı olarak magnezyum sülfat $\left(\mathrm{MgSO}_{4}\right)$, kalsiyum klorür $\left(\mathrm{CaCl}_{2}\right)$ ve etilen-diamin-ferrik (Fe-EDDHA) (etilen diamin tetra asetik asit (FeEDTA) yerine) miktarları \%25 oranında artırılmış modifiye MS ortamı kullanılmıştır. Sürgün çoğaltma aşamasında üç farklı konsantrasyonundaki benziladenin $(\mathrm{BA})(1,1.5$ ve 2 $\mathrm{mg} / \mathrm{l}$ )'nin 0 ve $0.1 \mathrm{mg} / \mathrm{l}$ konsantrasyonundaki naftalin asetik asit (NAA) ile yapmış olduğu 6 farklı kombinasyon kullanılarak, sürgün gelişimi üzerindeki etkileri incelenmiştir. Ortamlara ayrıca $30 \mathrm{~g} / \mathrm{l}$ sakkaroz ilave edilmiştir. In vitro koşullarda tomurcukların sürmesiyle elde edilen sürgünler, içinde bu sıvı ortamdan $20 \mathrm{ml}$ bulunduran $350 \mathrm{ml}$ 'lik kavanozlara yerleştirilerek, sıcaklı̆g $24 \pm 1{ }^{\circ} \mathrm{C}$ olarak ayarlanmıș iklim odasında, 16 saat aydınlık 8 saat karanlık ve 3000 lüks ışık yoğunluğunda kültüre alınmışlardır. Araştırma ile ilgili denemeler 3 
tekerrürlü, her tekerrürde 3 kavanoz ve her kavanozda da 3 sürgün olacak şekilde kurulmuştur. Kültürler 1 ay aralıklarla $3 \mathrm{kez}$ aynı besin ortamları kullanılarak alt kültüre alınmışlardır.

\subsubsection{Sürgünlerin köklendirilmesi}

Sürgün ortamlarında elde edilen sürgünler, daha sonra köklendirilmek amacıyla öncelikle $2 \mathrm{mg} / \mathrm{l}$ indol bütirik asit (IBA), $30 \mathrm{~g} / \mathrm{l}$ sakkaroz, ve $162 \mathrm{mg} / \mathrm{l}$ floroglusinol (PG) içeren $1 / 2$ MS ortamlarda 7 gün karanlıkta kültüre alınmıșlardır. Daha sonra sürgünler, $1 / 2 \mathrm{MS}$ ve $1 / 2$ modifiye $\mathrm{MS}(\mathrm{MMS})\left(\mathrm{MgSO}_{4}\right.$, $\mathrm{CaCl}_{2}$ ve $\mathrm{Fe}$-EDDHA (FeEDTA yerine) miktarları \%25 oranında artırılmış) ortamı olmak üzere iki farklı sıvı besin ortamında kültüre alınmışlardır. Her iki besin ortamına sadece $30 \mathrm{~g} / \mathrm{l}$ sakkaroz ilave edilmiştir. Kültürler aynı şekilde sıcaklığı $24 \pm 1{ }^{\circ} \mathrm{C}$, ışıklanma şiddeti 3000 lüks olarak ayarlanmış iklim odasında 16 saat aydınlık 8 saat karanlık koşullarda 1.5 ay süreyle kültüre alınmışlardır. Kültür sonrasında kökler steril saf su ile yıkanmalarının ardından, tartım ve ölçüm işlemlerine tabi tutulmuşlardır. Daha sonra sterilize edilmiş 2:1 oranında torf ve perlit karışımı içeren saksılara aktarılmışlardır.

\subsection{4. İncelenen özellikler}

Sürgün ortamında her bir alt kültür sonrasında ortalama sürgün uzunluğu, eksplant başına sürgün sayısı; köklenme aşamasında köklenme oranı ve ortalama kök sayısı, elde edilen in vitro bitkilerde de ortalama yaş bitki ağırlığı ve ortalama bitki uzunluğu değerleri incelenmiştir.

\section{3. İstatistik analizler}

Araștırma faktöriyel düzende tesadüf blokları deneme desenine göre kurulmuş olup, elde edilen verilerin istatistik analizleri SPSS 16.0 istatistik programı kullanılarak yapılmıştır. Uygulamalar arasındaki farklılıklar Duncan Çoklu Karşılaştırma Testi ile belirlenmiștir.

\section{Bulgular}

\subsection{Sürgün gelişimine ilişkin elde edilen bulgular}

R. damascena türüne ait yeşil sürgünlerin orta kısımlarından alınan boğumlardaki gözlerin, ilk dikim ortamı olarak kullanılan $30 \mathrm{~g} / \mathrm{l}$ sakkaroz içeren MS ortamlarında sürmesiyle elde edilen 4-5 cm uzunluğundaki sürgünler, daha sonra farklı konsantrasyonlarda $\mathrm{BA}$ ve NAA içeren $\mathrm{MgCL} 2, \mathrm{CaCl}_{2}$ ve FeEDDHA (Na-EDTA yerine) içerikleri \%25 oranında artırılmış sıvı MMS ortamlarında kültüre alınmışlardır. Sürgünlerin 1 ay aralıklarla $3 \mathrm{kez}$ alt kültüre alındıkları araştırmada (Şekil 1), her bir alt kültürde elde edilen eksplant bașına sürgün sayısı ve sürgün uzunlukları değerleri Tablo 1'de sunulmuştur.
Tablo 1. BA ve NAA uygulamalarına göre 3 alt kültürde sürgün gelișimi

\begin{tabular}{|l|c|c|}
\hline Ortamlar & $\begin{array}{l}\text { SS/E* } \\
\text { (adet) }\end{array}$ & $\begin{array}{c}\text { SU** } \\
\text { (cm) }\end{array}$ \\
\hline BA (1 mg/l) & \multicolumn{2}{|c|}{ 1. Alt Kültür } \\
\hline BA (1.5 mg/l) & $1.04 \mathrm{~b}^{* * *}$ & $3.22 \mathrm{~d}$ \\
\hline BA (2 mg/l) & $1.08 \mathrm{~b}$ & $4.31 \mathrm{a}$ \\
\hline BA (1 mg/l)+NAA $(0.1 \mathrm{mg} / \mathrm{l})$ & $1.39 \mathrm{a}$ & $4,35 \mathrm{a}$ \\
\hline BA (1.5 mg/l)+NAA $(0.1 \mathrm{mg} / \mathrm{l})$ & $1.07 \mathrm{~b}$ & $3.35 \mathrm{~cd}$ \\
\hline BA (2 mg/l)+NAA $0.1 \mathrm{mg} / \mathrm{l})$ & $1.05 \mathrm{~b}$ & $3.88 \mathrm{~b}$ \\
\hline & \multicolumn{2}{|c|}{ 2. Alt Kültür } \\
\hline BA (1 mg/l) & $2.84 \mathrm{~b}$ & $4.36 \mathrm{~b}$ \\
\hline BA (1.5 mg/l) & $2.88 \mathrm{~b}$ & $5.19 \mathrm{ab}$ \\
\hline BA (2 mg/l) & $3.84 \mathrm{a}$ & $5.49 \mathrm{a}$ \\
\hline BA (1 mg/l)+NAA (0.1 mg/l) & $2.82 \mathrm{~b}$ & $4.61 \mathrm{ab}$ \\
\hline BA (1.5 mg/l)+NAA $(0.1 \mathrm{mg} / \mathrm{l})$ & $2.47 \mathrm{c}$ & $5.21 \mathrm{ab}$ \\
\hline BA (2 mg/l)+NAA $(0.1 \mathrm{mg} / \mathrm{l})$ & $2.87 \mathrm{~b}$ & $5.18 \mathrm{ab}$ \\
\hline & \multicolumn{2}{|c|}{3. Alt Kültür } \\
\hline BA (1 mg/l) & $3.77 \mathrm{bc}$ & $5.43 \mathrm{~b}$ \\
\hline BA (1.5 mg/l) & $3.87 \mathrm{~b}$ & $6.60 \mathrm{a}$ \\
\hline BA (2 mg/l) & $4.58 \mathrm{a}$ & $6.63 \mathrm{a}$ \\
\hline BA (1 mg/l)+NAA(0.1 mg/l) & $3.34 \mathrm{~d}$ & $5.33 \mathrm{~b}$ \\
\hline BA (1.5 mg/l)+NAA(0.1 mg/l) & $3.43 \mathrm{~cd}$ & $5.45 \mathrm{~b}$ \\
\hline BA (2 mg/l)+NAA(0.1 mg/l) & $3.69 \mathrm{bc}$ & $5.89 \mathrm{~b}$ \\
\hline
\end{tabular}

*SS/ESürgün sayısı/eksplant,

**SU:Sürgün uzunluğu,

****Aynı sütunda farklı harflerle gösterilen ortamlar arasında istatistiksel olarak önemli derecede farklılık vardır $(\mathrm{p}<0.05)$.

Tablo 1'in incelenmesinden de anlaşılacağı üzere, 3 alt kültür süresince eksplant başına sürgün sayısı ve sürgün uzunluğunun kullanılan BA ve NAA konsantrasyonlarına bağlı olarak önemli derecede değiștiği tespit edilmiştir. Buna göre en yüksek eksplant başına sürgün sayısının 1. alt kültürde 1.39, 2. alt kültürde 3.84 ve 3 . alt kültürde 4.58 ile $2 \mathrm{mg} / \mathrm{l}$ BA ilave edilmiş besin ortamından elde edildiği; diğer uygulamalar arasında ise kültür sayısı arttıkça istatistiki olarak farklılıkların da arttığı görülmüştür. Sürgün uzunlukları değerleri incelendiğinde ise, 1 . ve 3. alt kültür aşamalarında 1.5 ve $2 \mathrm{mg} / \mathrm{l} \mathrm{BA}$ ilave edilmiş ortamlardan diğer ortamlara göre önemli derecede daha uzun sürgün elde edilirken, 2. alt kültürde ise en düșük değerin elde edildiği $1 \mathrm{mg} / \mathrm{l}$ BA ilave edilmiş ortam dışında diğer ortamlar arasında istatistiksel olarak bir farklılığın bulunmadığı tespit edilmiştir.

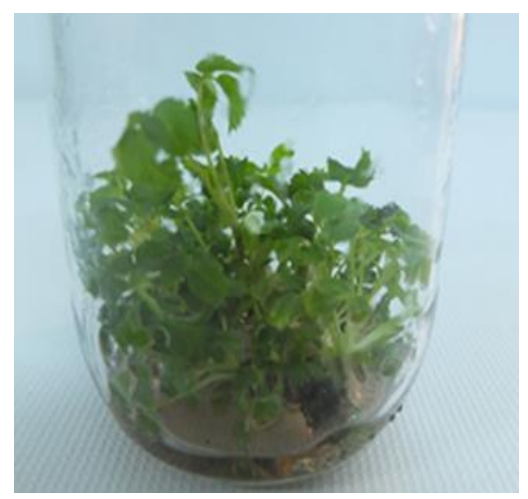

Şekil 1. Rosa damascena'ya ait in vitro sürgünler 


\subsection{Kök gelişimine ilişskin elde edilen bulgular}

Sürgün ortamlarında uzunluğu $3 \mathrm{~cm}$ ve daha fazla olan sürgünler, köklendirilmek için öncelikle $2 \mathrm{mg} / \mathrm{l}$ IBA, $30 \mathrm{~g} / \mathrm{l}$ sakkaroz ve $162 \mathrm{mg} / \mathrm{l}$ floroglusinol (PG) içeren $1 / 2 \quad$ MS ortamlarda 7 gün karanlıkta bekletilmelerinin ardından, sadece $30 \mathrm{~g} / \mathrm{l}$ sakkaroz içeren $1 / 2 \mathrm{MS}$ ile $\mathrm{MgSO}_{4}, \mathrm{CaCl}_{2}$ ve Fe-EDDHA (FeEDTA yerine) miktarları \%25 oranında artırılmıș $1 / 2$ modifiye MS (MMS) ortamı olmak üzere iki farklı sıvı besin ortamında kültüre alınmıșlardır. İki aylık süre sonunda köklenme oranının kullanılan ortamlara göre değiştiği tespit edilmiştir. Buna göre $1 / 2$ MS ortamında kültüre alınan sürgünlerin, \%71.11 köklenme oranı ile $1 \frac{1}{2}$ MMS ortamındaki sürgünlere göre daha yüksek oranda köklendikleri tespit edilmiştir (Şekil 2). MMS ortamında ise köklenme oranının \%46.34 olarak gerçekleşmiştir (Şekil 3.A). Köklenme ile ilgili bir diğer kriter ise kök sayısı olup, köklenme oranına benzer şekilde yine en yüksek kök sayıs $1 / 2$ MS ortamından elde edilmiștir. $1 / 2$ MMS'de 4.09 olan kök sayısının, $1 / 2$ MS ortamında 5.22'ye yükseldiği belirlenmiștir (Şekil 3.B).

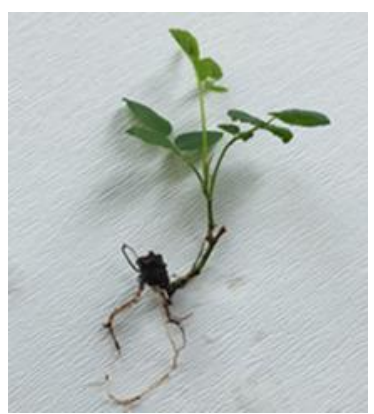

Şekil 2. Rosa damascena'ya ait köklenmiş bir bitki
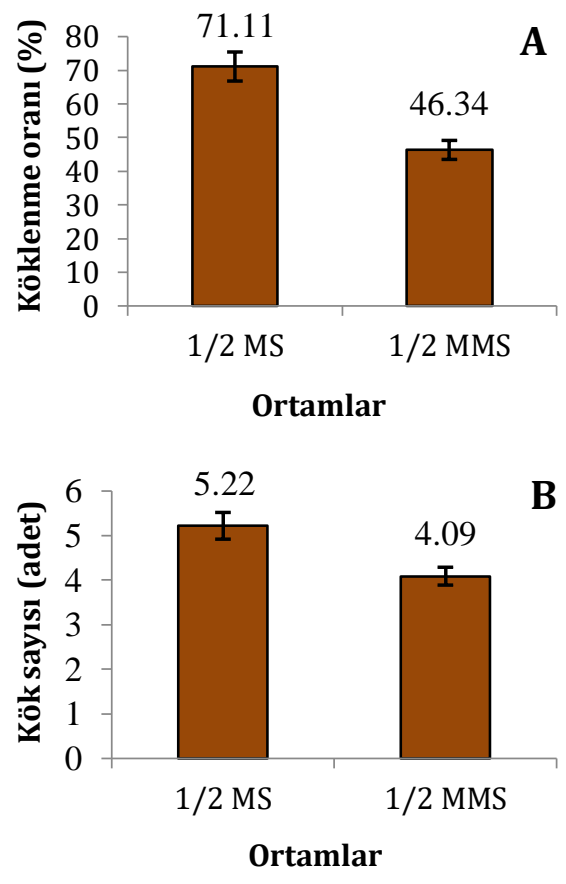

Şekil 3. Ortamlara göre köklenme oranı (A) ve kök sayısı (B)

\subsection{Bitki gelişimine ilişkin elde edilen bulgular}

İki aylık köklenme periyodu sonunda elde edilen bitkiler, bitki gelișimi ile iliş̧kili olarak ortalama bitki uzunluğu ve bitki ağırlığı kriterleri bakımından değerlendirilmişlerdir. Buna göre ortalama bitki uzunluğu bakımından en yüksek değer 8.21 ile $1 / 2$ MS besin ortamında kültüre alınan bitkilerden elde edildiği ve bu kriter bakımından $1 / 2$ MMS ortamındaki bitkiler ile arasında $1 \mathrm{~cm}$ 'den daha fazla bir farkın olduğu tespit edilmiștir (Şekil 4A). Bitki gelișimi ile ilgili bir diğer kriter olan ortalama bitki ağırlığının kullanılan besin ortamlarına göre önemli bir farklılık göstermediği tespit edilmiştir. $1 / 2$ MS ortamında kültüre alınan bitkilerin ağırlığı $1.77 \mathrm{~g}$; $1 / 2$ MMS ortamında gelişen bitkilerin ağırlı̆g $1.54 \mathrm{~g}$ olarak belirlenmiştir (Şekil 4.B). Daha sonra 2:1 oranında torf ve perlit karıșımı içeren saksılara aktarılan bitkilerden de \%78'inin de iyi bir gelişme gösterdiği tespit edilmiştir (Şekil 5).
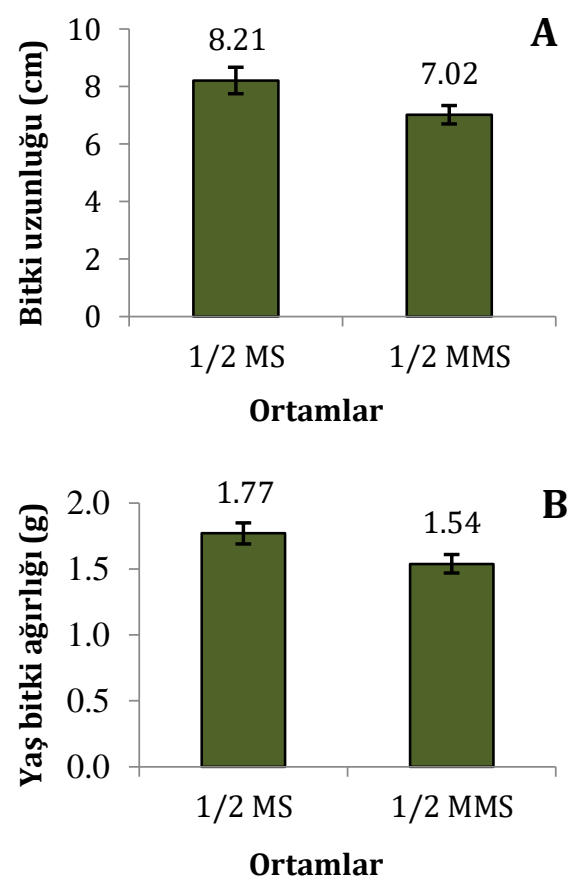

Şekil 4. Ortamlara göre bitki uzunluğu (A) ve yaş bitki ağırlığı (B)

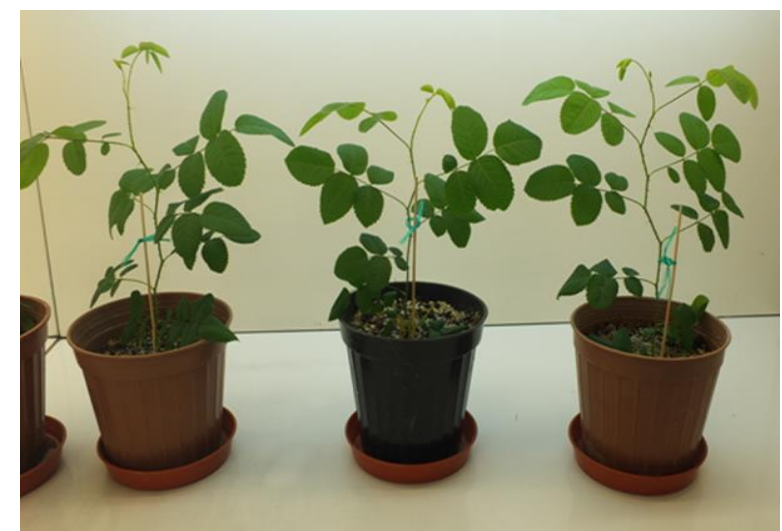

Şekil 5. Saksılara alınmış Rosa damascena bitkileri 


\section{Tartışma ve Sonuç}

In vitro mikroçoğaltım güllerde elit klonların kısa sürede çoğaltılması, hastalıklardan ari sağlıklı materyallerin elde edilmesi, mevsimlere bağll kalmaksızın yılın her döneminde üretimin yapılabilmesi gibi bir çok avantaja sahip olan ve bu nedenle de son yıllarda büyük popülarite kazanmış bir kültür tekniğidir [6].

Araştırmada bitkisel materyal olarak yeşil sürgünlerin orta kısımlarındaki 0.4-0.6 mm kalınlığındaki tez gözlü boğum parçaları kullanılmıştır. Benzer şekilde daha önce yapılan birçok araştırmada da tek gözlü boğum eksplantlarının $R$. damascena'nın çoğaltımında başarı ile kullanıldığı belirlenmiştir [7,10,11,12]. Nitekim eksplant olarak sürgün uçları kullanıldığında yoğun kahverengileşme nedeniyle eksplantların kısa sürede kaybedildiği ve bitki gelişiminin bu eksplantlarla gerçekleşmediği bildirilmiştir [13]. Bu nedenle de kararmanın daha az olduğu boğumların sürdürülmesi ile elde edilen lateral sürgünlerin, gül için daha uygun bir eksplant kaynağı olduğu ve sürgün uçları ile kıyaslandığında boğum eksplantlarının gülün çoğaltılmasındaki performansının çok daha yüksek oranlarda gerçekleştiği bildirilmiştir [6].

MS besin ortamı güllerin mikroçoğaltımında en yaygın olarak kullanılan ortamdır $[7,12]$. Besin ortamlarında belirli mineral maddelerin artırılmasının $R$. damascena'da mikroçoğaltım sırasında elde edilen sürgünlerin miktar ve kalitesini değiștirdiği bilinmektedir. $\mathrm{Bu}$ nedenle araștırmada sürgün ortamında demir kaynağı olarak FeEEDTA kullanılmış olup, FeEEDTA, $\mathrm{CaCl} 2$ ve $\mathrm{MgCl} 2$ miktarları \%25 oranında artırılmıştır. Nitekim Podwyszynska ve Olszewski [14], besin ortamlarında $\mathrm{CaCl}_{2}$ miktarının iki katına çıkarılması ile yapraklardaki sararmanın azaltıldığını belirlemişlerdir. Benzer şekilde Noodezh vd. [8] de $\mathrm{CaCl}_{2}$ 'nin 1.5 kat artırılmasının başlangıç ortamında sürgün gelişimini uyardığı, ileriki sürgün çoğalma aşamalarında da elde edilen sürgünlerin kalitesini arttırdığı ve yapraklarda sararmaların görülmediğini belirlemişlerdir. Araştırıcılar ayrıca amonyum nitrat miktarının besin ortamlarında artırılmasının sürgün büyümesini artırdığını; yaprakların daha koyu ve daha sağlıklı olmasına neden olduğunu belirlemişlerdir. Van der Salm vd. [15] de güllerde demir, magnezyum, manganez, kalsiyum gibi minerallerin miktarının artırılmasının oluşan sürgünlerin kalitesini önemli ölçüde artırdığını bulmuşlardır. Ayrıca demir kaynağı olarak FeEDTA yerine FeEDDHA kullanılmasının $R$. hybrida'da [15] ve $R$. damascena'da [8] daha başarılı sonuçlar verdiği belirlenmiştir. FeEEDHA'nın sürgün aşamasında daha uzun sürgün, geniş yapraklar ve yapraklarda daha yüksek klorofil birikimini sağladığı tespit edilmiştir[15].
Büyümeyi düzenleyici maddelerin miktar ve ortamlara verilme formu in vitro mikroçoğaltım çalışmalarında sürgün ve kök gelişimini önemli ölçüde değiştirmektedir. Bu araştırmada 1, 1.5 ve 2 mg/l konsantrasyonlarındaki BA'nın tek ya da 0.1 mg/l NAA ile yapmış olduğu kombinasyonlarının sürgün sayısı ve uzunluğuna olan etkisi incelenmiştir. Araştırmada $2 \mathrm{mg} / \mathrm{l}$ BA ilave edilmiş olan besin ortamı, sürgün sayısı ve sürgün uzunluğu bakımından en yüksek değerlerin elde edildiği besin ortamı olarak tespit edilmiştir. Benzer şekilde. R. damascena'da sürgün gelişimi için sitokininlerin mutlak gerekli olduğu tespit edilmiştir [16]. Salekjalali [12], sürgün gelişimi aşamasında besin ortamına ilave edilen 2 mg/l BA'nın $R$. damascena'da 1 ve $3 \mathrm{mg} / \mathrm{l}$ BA uygulamasına göre daha yüksek sürgün ve yeşil yaprak sayısına neden olurken, kahverengi yaprak sayısını ise azalttığını belirlemiștir. R. hybrida'da sürgün çoğalması aşamasında besin ortamına katılan $2 \mathrm{mg} / \mathrm{I}$ konsantrasyonundaki BA'nın sürgün çoğalma oranı ve sürgün gelişimini uyarırken, BA konsantrasyonunun artmasının sürgün oluşumunu azalttığı tespit edilmiştir [17]. Nikbakht vd. [11] ile Carelli ve Echeverrigary [18] de yüksek BA konsantrasyonlarının anormal sürgün gelişimini uyardığı ve sonraki alt kültürlerde bu sürgünlerin gelişemediğini belirlemişlerdir. Sürgün ortamında NAA'nın tek başına kullanıldığı $R$. hybrida ve $R$. damascena'da yapılan çalışmalar sonucunda, sürgün gelişimi ve çoğalması üzerinde önemli bir etkisinin olmadığı, 2 mg/l BA ile birlikte sürgün ortamına ilave edilen $0.1 \mathrm{mg} / \mathrm{l}$ NAA'nın ise sadece $2 \mathrm{mg} / \mathrm{l}$ BA'nın kullanıldığı ortamla klyaslandığında sürgün çoğalması üzerine önemli bir etkisinin olmadığı tespit edilmiştir [12,19]. Mamaghani vd. [20], R. damascena türünde sürgün çoğalması așamasında BA'nın kinetinden daha etkili olduğunu bulmuşlardır. Kullanılan BA konsantrasyonu alt kültürler süresince elde edilen sürgün sayısını da etkilemektedir. Nitekim bu araştırmada $1,1.5$ ve $2 \mathrm{mg} / \mathrm{l}$ konsantrasyonunda kullanılan BA'nın, yapılan 3 alt kültür sonrasında alt kültür sayısı arttıkça sürgün sayısının da arttığı tespit edilmiştir. Benzer şekilde bodur güllerlerde ve $R$. chinensis türünde alt kültür sayısının artmasına bağlı olarak sürgün sayısının da arttığı belirlenmiştir [21,22]. Jabbarzadeh ve KhoshKhui [11] ise $R$. damascena da $2.5-3 \mathrm{mg} / \mathrm{l}$ gibi daha yüksek BA konsantrasyonları kullandıklarında alt kültür sayısı arttıkça sürgün sayısında bir azalmanın ortaya çıktığını belirlemișlerdir. Bu durum yüksek konsantrasyonlarda kullanılan BA'nın kültürün ileri aşamalarında sürgün gelişimini sınırlandırıcı bir etkide bulunması şeklinde açıklanabilir.

Köklenme aşamasında, sürgünler önce 2 mg/l IBA, 30 $\mathrm{g} / \mathrm{l}$ sakkaroz ve $162 \mathrm{mg} /$ l floroglusinol (PG) içeren 1/2 MS ortamında 7 gün süreyle karanlıkta tutulmuş, ardından $30 \mathrm{~g} / \mathrm{l}$ sakkaroz içeren $1 / 2$ MS ile $1 / 2$ MMS ortamlarına aktarılmışlardır. $R$. damascena'da köklerin 2 haftadan daha uzun süre oksin içeren köklenme ortamında tutulmalarının, kök uçlarının 
kahverengileşmesine ve sürgünlerin birkaç gün içinde canlılıklarını yitirmelerine neden olduğu bildirilmektedir [11]. Bu problem kültürlerin oksin içeren kök çlkışını başlatma ortamından, büyümeyi düzenleyici madde içermeyen kök uzama ortamlarına transfer edilmesiyle çözümlenebilmiştir. Nitekim oksinlerin kök oluşumu için gerekli olduğu ancak, kök gelişiminin ileriki aşamalarında gerekli olmadığı ifade edilmektedir [11]. Pati vd. [7] ise BA ilave edilmiş ortamlarda 7 gün tutulup, ardından büyümeyi düzenleyici madde içermeyen sıvı ortamlara aktarılan sürgünlerde köklenmenin başarı ile elde edildiğini ifade etmişlerdir.

Araștırmada 1/2 MS ortamında, 1/2 MMS ortamına göre hem köklenme oranı hem de kök sayısı bakımından daha yüksek değerlerin elde edildiği belirlenmiştir. Ayrıca $1 / 2$ MS ortamında kültüre alınarak köklendirilen bitkilerin yaş ağırlıkları ile bitki uzunluklarının da 1/2 MMS ortamındakilere göre daha yüksek olduğu tespit edilmiștir. Khosh-Khui ve Sink [19] ile Kirichenko vd. [23] R. damascena'nın modern güllere göre daha zor köklendiğini ifade ederken; benzer şekilde $R$. damascena'da köklenmenin sürgün gelişimine göre çok daha zor olduğunu ifade eden Salekjalali [12], $2 \mathrm{mg} /$ IBA içeren $1 / 2$ MS ortamında $\% 80$ oranında köklenmenin elde edildiğini ve bu yönüyle en yüksek köklenmenin bu uygulamadan elde edildiğini belirlemiştir. Saffari vd. [24] ise $R$. damascena için büyümeyi düzenleyici içermeyen MS ortamının, 1, 2 ve $4 \mathrm{mg} / \mathrm{l}$ IBA içeren MS ortamlarına göre daha başarılı sonuç verdiğini ve büyümeyi düzenleyici madde içermeyen ortamlarda köklenmenin \%52.17 ile en yüksek değere ulaştığını belirlemişlerdir.

$\mathrm{Bu}$ araştırmada köklenme ortamlarına $162 \mathrm{mg} / \mathrm{l}$ konsantrasyonunda floroglusinol ilave edilmiştir. Floroglusinol ksilem öz suyunda bulunan bir filoridzin türevi olup, bitkilerde büyüme ve gelişmeyi teşvik ettiği $[25,26]$, in vitro koşullarda ortaya çıkan vitrifikasyon problemini azalttığı [27], asıl kullanımının ise köklenme üzerine olduğu belirlenmiștir $[28,29]$. Floroglusinolün ayrıca aerobik metabolizma süresince oluşan ve doku kültürü süresince hücre ölümlerine, doku zararlarına ve nekrozlara neden olan eksplantların süperoksit anyonları, hidroksil ve hidrojen peroksit gibi reaktif oksijen türevlerine karşı antioksidan etkilerinin olduğu da tespit edilmiştir [30]. Noodezh vd. [8] de floroglusinolün $R$. damascena'da köklenme üzerinde olumlu etkilerde bulunduğunu ifade etmişlerdir.

$\mathrm{Bu}$ araştırmada hem sürgün hem de köklenme aşamasında sıvı ortamlar kullanılmıştır. Sıvı besin ortamlarının bitki gelişimi üzerindeki etkileri farklı gül türlerinde yapılan çalışmalarla ortaya konulmaya çalıșılmıştır [22,31]. Pati vd. [7], $R$. damascena ve $R$. bourboniana türlerinde sürgün aşamasında hem agarla katılaştırılmış ortamları hem de sıvı ortamları kullanmışlardır. Araştırıcılar agarlı ortamlarda yetişen sürgünlerde hem bazı nekrozların görüldüğünü, hem de sıvı ortamlardakilere göre daha ince ve daha az sürgün olușturduklarını tespit etmişlerdir. Nikbakht vd. [10] de $R$. damascena'da katı ortamlarda ortaya çıkan yaşlanma problemi ve buna bağlı olarak sürgün çoğalmasının azalmasının sıvı ortamlar kullanılarak çözülebileceğini belirtmişlerdir. Pati vd. [7], düşük maliyet, daha yüksek sürgün çoğalması ve köklenme oranı sağlayan sıvı ortamların $R$. damascena'da başarı ile uygulanabileceğini belirtmişlerdir. Sıvı ortamların güllerde katı ortamlara göre daha başarılı sonuç vermesinin, sıvı ortamların büyümeyi düzenleyici ve diğer besin maddelerinin alınımını arttırması [32], eksplantların kesim yerlerinden ortama salınan kahverengi bileşikleri seyreltmesi [33] ve kültürün daha iyi havalanmasını sağlaması [34] gibi nedenlerden kaynaklandığı bildirilmektedir. Pati vd. [7] ile Ghashghaie vd. [35] agarın besin ortamlarında ozmotik potansiyeli teșvik ederek özellikle mikro sürgünlerin köklenmesini etkilediğini belirlemişlerdir. Köklendirme ortamlarında hem sıvı hem de agarla katılaştırılmış ortamları kullanan Pati vd. [7], R. damascena türüne ait sürgünlerin, katı ortamlardaki köklenme oranının \%5 ile sınırlı kalırken; sıvı ortamlarda bu oranın \%85.8'e yükseldiğini ifade etmişlerdir. Benzer şekilde Noodezh vd. [8] de $R$. damascena'da köklenme oranının sıvı ortamlarda daha yüksek olduğunu belirlemişlerdir. Agarın elimine edildiği sıvı ortamların kullanılması hem maliyet hem de mikroçoğaltımda daha başarılı sonuçların elde edilmesi nedeniyle tercih edilen bir yöntem olduğu daha önce yapılan çalışmalarla da tespit edilmiştir $[7,8]$.

Sonuç olarak, araştırmada tek gözlü boğumların büyümeyi düzenleyici madde içermeyen katı MS ortamında sürdürülmesi ile elde edilen sürgünlerin çoğaltılmasında, $2 \mathrm{mg} / \mathrm{l} \mathrm{BA}$ içeren sıvı modifiye MS ortamının; sürgünlerin köklendirilmesinde de 7 gün süreyle $2 \mathrm{mg} / \mathrm{l}$ IBA, $30 \mathrm{~g} / \mathrm{l}$ sakkaroz ve $162 \mathrm{mg} / \mathrm{l}$ floroglusinol içeren MS ortamında tutulmalarının ardından sadece $30 \mathrm{~g} / \mathrm{g}$ sakkaroz içeren sıvı 1/2 MS ortamlarına transfer edilmeleri ile $R$. damascena'nın in vitro koşullarda başarı ile çoğaltılabileceği tespit edilmiştir. Araştırmada ayrıca düşük maliyet ve yüksek başarı ile $R$. damascena türü için sıvı ortamların başarı ile kullanılabilecek önemli bir potansiyele sahip olduğu da belirlenmiştir.

\section{Tessekkür}

$\mathrm{Bu}$ araştırma 5001-YL1-17 Proje Numarası ile Süleyman Demirel Üniversitesi Bilimsel Araștırma Projeleri Koordinasyon Birimi tarafindan desteklenmiş olup, "Yağ Gülünün (Rosa Damascena Mill.) In Vitro Çoğaltımı" konulu yüksek lisans tezinden üretilmiștir. 


\section{Kaynakça}

[1] Baydar, H., Erbaș, S., Kıneci, S., Kazaz, S., 2007. Yağ Gülü (Rosa damascena Mill.) Damitma Suyuna Katılan Tween-20'nin Taze ve Fermente Olmuş Çiçeklerin Gül Yağı Verimi ve Kalitesi Üzerine Etkisi. Süleyman Demirel Üniversitesi Ziraat Fakültesi Dergisi, 2, 15-20.

[2] Baydar, H., 2013. Tıbbi, Aromatik ve Keyif Bitkileri Bilimi ve Teknolojisi. Süleyman Demirel Üniversitesi Yayın Evi, 20-50s, Isparta.

[3] Khosh-Khui, M., 2014. Biotechnology of Scented Roses: A Review. International Journal of Horticultural Science and Technology, 1, 1-20.

[4] Özkan, G., Sağdıç, O., Göktürk Baydar, N., Baydar, H., 2004. Antioxidant and Antibacterial Activities of Rosa damascena flower extracts. Food Science and Technology International, 10(4), 277-281.

[5] Mileva, M., Krumova, E., Miteva-Staleva, J., Kostadinova, N., Dobreva, A., Galabov, A.S., 2014. Chemical Compounds, In Vitro Antioxidant and Antifungal Activities of Some Plant Essential Oils Belonging to Rosaceae Family. Comptes Rendus De L Academie Bulgare Des Sciences, 67, 13631368.

[6] Horn, W.A.H., 1992. Micropropagation of Rose (Rosa L.). In: Bajaj YPS (ed) Biotechnology in Agriculture and Forestry, Vol. 20, High- Tech and Micropropagation IV (pp. 320-342). Springer, Germany.

[7] Pati, P. K., Sharma, M., Sood, A., Ahuja, P. S., 2005. Micropropagation of Rosa damascena and $R$. bourboniana in Liquid Cultures. In Liquid Culture Systems for in Vitro Plant Propagation, Springer, 373-385.

[8] Noodezh, H. M., Moieni, A., Baghizadeh, A., 2012. In Vitro Propagation of the Damask Rose (Rosa damascena Mill.). In Vitro Cellular and Developmental Biology-Plant, 48, 530-538.

[9] Murashige, T., Skoog, F., 1962. A Revised Medium for Rapid Growth and Bio Assays with Tobacco Tissue Cultures. Physiologia Plantarum, 15, 473-497.

[10] Nikbakht, A., Kafi, M., Mirmasoudi, M., Babalar, M., 2005. Micropropagation of Damask Rose (Rosa damascena Mill.) cvs. Azaran and Ghamsar. International Journal of Agricultural and Biological Engineering, 7, 535-538.

[11] Jabbarzadeh, Z., Khosh-Khui, M., 2005. Factors Affecting Tissue Culture of Damask Rose (Rosa damascena Mill.). Scientia Horticulturae, 105, 475-482.

[12] Salekjalali, M., 2012. Phloroglucinol, BAP and NAA Enhance Axillary Shoot Proliferation and other Growth Indicators In vitro Culture of Damask Rose (Rosa damascena Mill.). American-
Eurasian Journal of Agricultural and Environmental Sciences, 12, 960-966.

[13] Gülșen, Y., Ağaoğlu, Y.S., Ellialtıoğlu, Ş., 1994. Isparta ve yöresinde yetiştirilen yağ gülünün (Rosa damascena Mill.) doku kültürü yoluyla çoğaltılması. TÜBİTAK GÜLAR 7 no'lu proje sonuç raporu. $45 \mathrm{~s}$.

[14] Podwyszynska, M., Olszewski, T., 1995. Influence of Gelling Agents on Shoot Multiplication and the Uptake of Macroelements by In Vitro Culture of Rose, Cordyline and Homalomena. Scientia Horticulturae, 64,77-84.

[15] Van der Salm, C., Van der Toon, C., Hanisch ten Cate, L., Dubois, D., Vries, H., 1994. Importance of the Iron Chelate Formula for Micropropagation of Rosa hybrida L. 'Moneyway'. Plant Cell, Tissue and Organ Culture, 37, 73-77.

[16] Alsemaan, T., Albatal, N., Almaarri, K., 2011. Micropropagation of Damask Rose (Rosa damascena). Arab Universities Journal of Agricultural Sciences, 19, 117-127.

[17] Attia, A. O., Dessoky, D.S., El-Tarras, A.E., 2012. In Vitro Propagation of Rosa hybrida L. cv. Al-Taif Rose Plant. African Journal of Biotechnology, 11(48), 10888-10893.

[18] Carelli, B.P., Echeverrigaray, S., 2002. An Improved System for the In Vitro Ppropagation of Rose Cultivars. Scientia Horticulturae, 92, 6974.

[19] Khosh-Khui, M., Sink, K.C., 1982. Micropropagation of New and old World Rose Species. Journal of Horticultural Sciences, 57, 315-319.

[20] Mamaghani, B. A., Ghorbanli, M., Assareh, M. H., Zare, A. G., 2010. In vitro Propagation of Three Damask Roses Accessions. Iranian Journal of Plant Physiology, 1, 85-94.

[21] Campos, P.S., Pais, M.S.S., 1990. Mass Propagation of the Dwarf Rose Cultivar Rosamini. Scientia Horticulturae, 43, 321-30.

[22] Chu, C.Y., Knight, S.L., Smith, M.A.L., 1993. Effect of Liquid Culture on the Growth and Development of Miniature Rose (Rosa chinensis Jacq. 'Minima'). Plant Cell, Tissue and Organ Culture, 32, 329-334.

[23] Kirichenko, E.B., Kuz'-Mina, T.A., Kataeva, N.V., 1991. Factors in Optimizing the Multiplication of Ornamental and Essential Oil Roses In Vitro. Byulleten'-Glavnogo-Botanicheskogo-Sada, 159, 61-67.

[24] Saffari, V.R., Sharifi-Sirchi, G.R., Torabi-Sirchi, M.H., 2011. Enhancing Rooting Consistency in Rosa damascena Scions. African Journal of Biotechnology, 10, 16495-16500. 
[25] Oliveria, A.J.B., Carvalho, V.M., Ferreira, A., Sato F.Y., Machado, M.F.P., 2003. In Vitro Multiplication of Tabernaemontana fuchsiaefolia L. (Apocynaceae). Revista Árvore, 27, 421-425.

[26] Bhot, M., S. Naphade, J. Varghese and N. Chandra, 2010. In Vitro Culture Studies in Three Varieties of Codiaeum Variegatum (L.) Blume Using Node Explants from Field Growth Plants. Journal of Cell and Tissue Research, 10, 2439-2444.

[27] Gaspar, T., 1991. Vitrification in Micropropagation. In: Bajaj Y.P.S. (ed.), Springer, Berlin.

[28] Modgil, M., Sharma, D.R., Bhardwaj, S.V., 1999. Micropropagtion of Apple cv. Tydeman's Early Worcester. Scientia Horticulturae, 81, 179-188.

[29] Wang, Q., 1991. Factors Affecting Rooting of Microcuttings of the Pear Rootstock BP10030. Scientia Horticulturae, 45, 209-213.

[30] Kim, J.A., Lee, J.M., Shin, D.B., Lee, N.H., 2004. The Antioxidant Activity and Tyrosinase Inhibitory Activity of Phlorotannins in Ecklonia cava. Food Science and Biotechnology, 13, 476-480.
[31] Ramesh, K., Dohare, S.R., Chopra, H.R., Kumar, R., 1993. In Vitro Effect of Growth Regulators and Media State on Seed Germination and Shoot Proliferation of Rose (Rosa hybrida). Punjab Horticultural Journal, 33, 142-146.

[32] Debergh, P.C., 1983. Effects of Agar Brand and Concentration on the Tissue Culture Medium. Physiologia Plantarum, 59, 270-276.

[33] Ziv, M., Halevy, A.H., 1983. Control of Oxidative Browning and In Vitro Propagation of Strelitzia reginae. Horticultural Sciences, 18 (4), 434-436.

[34] Ibrahim, A.I., 1994. Effect of Gelling Agent and Activated Charcoal on the Growth and Development of Cordyline terminalis Cultured In Vitro. In: Proceedings of the First Conference of Ornamental Horticulture, 1, 55-67 pp.

[35] Ghashghaie, J., Brenckmann, F., Saagier, B., 1991. Effects of Agar Concentration on Water Status and Growth of Rose Plants Cultured in Vitro. Physiologia Plantarum, 82, 73-78. 